Karin Finsterbusch

\title{
Antisemitic Positions in Christian Holy Scriptures: The Idea of Israel's Election and its Challenge for New Testament Authors and for their Readership
}

The religious idea of Israel as a chosen people has consistently played an important role in Christian antisemitic polemics. For example, in his well-known book On the Jews and Their Lies (Von den Jüden und jren Lügen), Martin Luther drew the picture of the boasting Jews with respect to God's election:

Then he (i.e., God) must hear how they are boasting and praising God that he has set them apart from the gentiles and has given them birth from the holy fathers and has chosen them to be a holy, treasured people etc. And there is no end and proportion of the boasting about the blood and the carnal birth from the fathers. ${ }^{1}$

Luther, however, left no doubt that the Jews were in his view by no means to be considered any longer as a chosen people, on the contrary:

Therefore, this angry deed (i.e., the destruction of Jerusalem) proves that the Jews, who are certainly rejected by God, are no longer his people and that he is no longer their God. This according to Hosea 1(:9): “Lo Ammi. For you are not my people and I am not your God.” [...] The Jews might think about our Lord Jesus what they want. We see that it happens as he said (in) Luke 21(:20-23): "When you see Jerusalem surrounded by an army then know that its desolation has come near. [...] And there will be great distress in the land and wrath against this people."

1 M. Luther, Von den Jüden und jren Lügen (1543), in: WA 53 (p. 419, line 36 - p. 420, line 3). In German: "Da mus er (i.e., Gott) hören, wie sie sich rhümen, Und Gott loben, das er sie hat von den heiden gesondert, Und von den heiligen Vetern geborn lassen werden, und zum heiligen eigen Volck erwelet etc. Und ist des rhümens vom geblüt und leiblicher Geburt von den Vetern kein mas noch ende."

2 M. Luther, Von den Jüden und jren Lügen (1543), in: WA 53 (p. 418, line 20 - p. 419, line 3). In German: "Darumb schleusst dis zornig Werck (i.e. die Zerstörung Jerusalems), das die Jüden, gewislich von Gott verworffen, nicht mehr sein volck sind, Er auch nicht mehr ir Gott sey. Und gehet nach dem Spruch Hosea I(:9): 'Lo Ammi. Ir seid nicht mein volck, So bin ich nicht ewr Gott.' [...] Wolan, die Jüden mugen unsern HErrn Jhesum halten, wo fur sie wollen, Wir sehen, das also gehet, wie er sagt Luce XXI(:20 - 23): 'Wenn ir sehen werdet Jerusalem belegert mit einem Heer so mercket, das erbey komen ist ihr verwustung, [...] Und wird grosse not im lande sein und zorn uber dis volck.””

๑ OpenAccess. (c) 2020 Karin Finsterbusch, published by De Gruyter. (cc) BY-NC-ND This work is licensed under the Creative Commons Attribution-NonCommercial-NoDerivatives 4.0 License. 
Although scholars after the Shoah became increasingly aware of antisemitic ${ }^{3}$ statements in the New Testament and of antisemitic patterns such as Supersessionism in the history of the Christian religion, ${ }^{4}$ the antisemitic-coined references to Israel and its election in several New Testament scriptures have as yet largely escaped notice: the earliest antisemitic reception of this idea, which is crucial for Judaism, has yet to be thoroughly analyzed. Such an analysis would require a book-length study, however, in this paper, I may draw attention to at least some important points.

The paper includes three main parts: In the first part, I will explain some central aspects of the idea of the chosen Israel according to one of the most relevant passages in the Torah. In the second part, I will focus on New Testament reception and will exemplarily analyze selected passages of three different authors. Finally, I will consider some of the ways in which today's Christian readership may deal with the antisemitic positions in the analyzed New Testament passages in an appropriate way.

3 I do not differentiate between antisemitism and anti-Judaism, this differentiation (according to which antisemitism should refer only to the racial aspect of hatred for Jews in modern times) is in my view problematic: the use of the term Antijudaism obscures not only the continuity between hatred for Jews from antiquity to present times, but it also conceals the role of the ancient/medieval patterns of hatred for Jews in preparing the culmination of antisemitism/antiJudaism in the Shoah. For a helpful definition of antisemitism, see https://european-forum-onantisemitism.org/definition-of-antisemitism/english-english.

4 See, for example, W. P. Eckert et al., eds., Antijudaismus im Neuen Testament? Exegetische und systematische Beiträge (München: Kaiser, 1967); R. Radford Ruether, Faith and Fratricide: The Theological Roots of Anti-Semitism (New York: Seabury, 1974); F. Mussner, Traktat über die Juden (München: Kösel, 1979); G. Theissen, “Aporien im Umgang mit den Antijudaismen des Neuen Testaments," in Die Hebräische Bibel und ihre zweifache Nachgeschichte. FS R. Rendtorff, ed. E. Blum et al. (Neukirchen-Vluyn: Neukirchener Verlag, 1990), 535-53; W. Dietrich et al., eds., Antijudaismus-christliche Erblast (Stuttgart: Kohlhammer, 1999); R. Bieringer et al., eds., Anti-Judaism and the Fourth Gospel: Papers of the Leuven Colloquium (Assen: Van Gorcum, 2001); T. L. Donaldson, Jews and Anti-Judaism in the New Testament: Decision Points and Divergent Interpretation (London: Baylor University Press, 2010); R. Chazan, From Anti-Judaism to Anti-Semitism: Ancient and Medieval Christian Constructions of Jewish History (New York: Cambridge University Press, 2016); U. A. Wien, ed., Judentum und Antisemitismus in Europa (Tübingen: Mohr Siebeck, 2017); D. Wendebourg et al., eds., Protestantismus, Antijudaismus, Antisemitismus: Konvergenzen und Konfrontationen in ihren Kontexten (Tübingen: Mohr Siebeck, 2017). 


\section{Israel as God's Chosen People according to Deuteronomy 7}

In Second Temple Judaism, in the aftermath of war, destruction, exile, and miraculous survival, the authors often describe the status of Israel ${ }^{5}$ in terms of election. The issue is undoubtedly multifaceted. ${ }^{6}$ Within the constraints of this paper, I will concentrate on Deut 7:6-11, a passage, which is often called a "locus classicus."7 In the world of Deuteronomy, the speaker of this passage is Moses, addressing his people on the plains of Moab just prior to their entry into the promised land:

6 For a consecrated people you (are) to YHWH your God: YHWH your God has chosen you to be his treasured people out of all peoples, that (are) on the face of the earth.

7 Not because you were in numbers more than any other people YHWH set his love upon you and chose you, for you (were) the fewest of all peoples.

8 But because YHWH's love for you and (because) he kept the oath that he had sworn to your fathers, YHWH brought you out with a mighty hand and rescued you from the house of slaves from the hand of Pharaoh king of Egypt.

9 And you shall know that YHWH your God is the God, the faithful God, keeping the covenant and grace with them who love him and who keep his commandments to the thousandth generation

10 and repaying them who hate him to their face, to destroy them. He will not be slow with one who hates him, to his face he will repay him.

5 "Israel" is used here in the sense of the proper name for the Jewish people.

6 See for example the first seven contributions in S. Almog and M. Heyd, eds., Chosen People, Elect Nation and Universal Mission (Jerusalem: Graf-Chen, 1991 [Hebrew]); S. Grindheim, The Crux of Election: Paul's Critique of the Jewish Confidence in the Election of Israel (Tübingen: Mohr Siebeck, 2005), 7-76. For interesting modern Jewish approaches to the meaning of the concept of Israel's chosenness, see W. G. Plaut, The Case for the Chosen People (New York: Doubleday, 1965); W. Herberg, “The 'Chosenness' of Israel and the 'Jew' of Today,” in Arguments and Doctrines: A Reader of Jewish Thinking in the Aftermath of the Holocaust, ed. A. A. Cohen (New York: Harper \& Row, 1970), 267-83; M. Wyschogrod, The Body of Faith: Judaism as Corporeal Election (Minneapolis: Seabury, 1983); D. Novak, "The Election of Israel: Outline of a Philosophical Analysis," in A People Apart: Chosenness and Ritual in Jewish Philosophical Thought, ed. D. H. Frank (New York: State University Press, 1993), 11-50; J. Gellman, "Jewish Chosenness and Religious Diversity-A Contemporary Approach,” in Religious Perspectives on Religious Diversity, ed. R. McKim (Leiden: Brill, 2016), 21-36.

7 Cf., for example, K. Seybold, "Erwählung. I Altes Testament," in Religion in Geschichte und Gegenwart: Handwörterbuch für Theologie und Religionswissenschaft, ed. H. D. Betz, 4th ed. (Tübingen: Mohr Siebeck, 1999), 2:1479. 
11 And you shall keep the commandment-the statutes as well as the judgements-which I command you today to do them.

The first important point to notice is that Israel's election is not shaped as an elitist concept: the election is solely based on divine love and by no means on Israel's strength (v. 7). Furthermore, the privilege of election aims at inducing Israel to live according to God's will (v. 11). This is, obviously, the very essence of the concept: the inseparable connection between election and Israel's (Torah-) obedience. $^{8}$ Finally, election is undoubtedly an exclusive concept: on the one hand the chosen people, on the other hand the not-chosen nations (v. 6). However, as other texts in the book of Deuteronomy show, not-chosen does not mean rejected. ${ }^{9}$ For example, according to Deut 4:19, God allotted to the gentile world deities in order to serve them. ${ }^{10}$ The designated religious ways for the nations certainly differ from that of Israel, but they are not considered as sinful or religiously illegitimate. This is a position which was held by other authors in Second Temple Judaism as well as in rabbinic Judaism, too. ${ }^{11}$

In sum: the conception of election within the developing monotheistic Jewish religion in antiquity did not lead inevitably to religious intolerance. At the same time, however, the construction of religious identity in the developing monotheistic Christian religion made it nearly impossible to value Israel as God's chosen people, as the following examples will demonstrate.

8 See as well Amos 3:2, and cf. L. H. Silberman, “Chosen People," in Encyclopaedia Judaica, ed. F. Skolnik and M. Berenbaum, 2nd ed. (Detroit: Macmillan Reference, 2007), 4:670.

9 See K. Finsterbusch, Deuteronomium: Eine Einführung (Göttingen: Vandenhoeck \& Ruprecht, 2012), $86-87$.

10 See J. H. Tigay, Deuteronomy (Philadelphia: Jewish Publication Society, 1996), xvi.

11 A prominent example is the idea of the Noahide commandments, see, for example, D. Novak, The Image of the non-Jew in Judaism: The Idea of the Noahide Law, 2nd ed. (Oxford: The Littman Library of Jewish Civilization, 2011). The general picture about the gentiles in the rabbinic literature is all in all negative. However, there are some remarkable exceptions, for example a Midrash on Deut 33:3 in Mekhilta Devarim: “'Also, he loves the nations': this teaches that with every love with which the Holy One, blessed be He, loves Israel, he loves the nations of the world," see M. Kahana, "Pages from the Deuteronomy Mekhilta on Haazinu and Wezot Haberakha,” Tarbitz 57 (1988): 180 - 81 [Hebrew]. 


\section{Israel and the Idea of Election in Selected New Testament Scriptures}

In the first century C.E., the followers of Jesus Christ, who believed him to be the nation's God-given Messiah, could not ignore the religious idea of the special status of Israel because this was testified in many Jewish Holy Scriptures, which they themselves accepted as authoritative. On the other hand, they were faced with the fact that the majority of the members of the chosen people did not accept Jesus as their Messiah. Consequently, the first Christians were forced to take up a stance with respect to this part of Israel.

\subsection{All Israel will be Saved: Israel as God's Chosen People in Romans 11}

Paul's latest-preserved epistle is the epistle to the Romans, written in the fifties of the first century C.E. The apostle, who did not know the Roman congregation personally, introduced himself and his theology in this epistle. He expounded many central issues, among others the question of the religious status of Israel in chapters 9-11. In the following, I quote parts of the passage 11:11-36. In this passage, Israel is compared with a deep-rooted cultivated olive tree, the addressed Roman Christian gentiles with a wild olive:

11:16 [...] And if the root (is) holy, so (are) the branches.

17 But if some of the branches were broken off and you, although being a wild olive, were grafted in among them and made to share the root (and) the fatness of the olive tree,

18 do not boast against the branches! But if you do boast, (remember) it is not you who support the root,

but the root that supports you.

19 Then you will say: "Branches were broken off in order that I might be grafted in."

20 True: they were broken off by (their) unbelief and you standest by (your) faith. Be not highminded, but fear!

21 For if God did not spare the natural branches neither will he spare you.

22 Note, then, the kindness and the severity of God: to those who fell, severity, but to you, kindness of God, if you continue in (his) kindness, otherwise you, too, will be cut off.

23 And they also, if they do not continue in (their) unbelief, will be grafted in, for God is able to graft them in again. 
24 For if you were cut off from a wild olive tree (to which you belong) by nature and were grafted contrary to nature into a cultivated olive tree, how much more will these, the natural (branches), be grafted into (their) own olive tree.

25 For I don't want you, brothers, to be ignorant of this mystery, lest you should be wise in your own sight: hardening has come in part upon Israel until the fullness of the Gentiles has come in.

26 And thus all Israel will be saved, as is written: "From Zion will come the deliverer, he will turn away iniquities from Jacob.

27 And this (is) my covenant for them, whenever I take away their sins."

28 As regards to the gospel, (they are) enemies (of God) for your sake, as regards to the election, (they are) beloved (of God) for the sake of the fathers (i.e., patriarchs),

29 for irrevocable (are) the gifts and (is) the calling of God.

In the last decades, it has often been emphasized that this passage contains some of the most positive statements on Israel in the whole New Testament. ${ }^{12}$ And indeed, according to 11:28, Israel is and will remain God's chosen people (via the patriarchs ${ }^{13}$ ); according to v. 26 and v. 27, all (!) Israel, this is the whole Jewish people, will finally be saved by God's own initiative ${ }^{14}$ at the end of times, which Paul expected to be soon to come. ${ }^{15}$

However, a closer look at the passage may complicate this friendly picture: Paul compared the non-Christ-believing ${ }^{16}$ Jews with branches of an olive tree

12 See, for example, F. Mussner, "Ganz Israel wird gerettet werden (Röm 11,26). Versuch einer Auslegung,” Kairos 18 (1976): 241-55; S. Vollenweider, “Antijudaismus im Neuen Testament. Der Anfang einer unseligen Tradition,” in Antijudaismus-christliche Erblast, ed. W. Dietrich et al. (Stuttgart: Kohlhammer, 1999), 50 - 55; G. Lohfink, “Antijudaismus bei Paulus?” in Im Ringen um die Vernunft: Reden über Israel, die Kirche und die Europäische Aufklärung (Freiburg: Herder, 2016), 335-66, 536- 43.

13 The idea that the election of the Patriarchs led to the election of the whole people is expressed in several texts in Second Temple Judaism (e.g., Isa 41:8-13, and cf. also Acts 13:17 below).

14 The quotation in Rom 11:26b-27 is a mixture of LXX Isa 59:20 - 21a and 27:9. The deliverer, mentioned in v. 26b, could be referring to God (as in Isaiah), or to Jesus Christ, thus the scholarly majority view, see Grindheim, Election, 167, note 115.

15 See Romans 13:11f.

16 The Christian exegetical literature is littered with biased terms like the "unbelieving Israel" or the "unbelief of Israel." An exception is M. Konradt, using the term "nicht-christusgläubige Juden," ("Die historisch-kritische Exegese und das reformatorische Schriftprinzip. Eine Reflexion über die Bedeutung der Exegese des Neues Testaments in der Theologie," Zeitschrift für Neues Testament 39/40 [2017]: 122). 
that were "broken off" by $\operatorname{God}^{17}$ (v. 17, 20); furthermore, the apostle described them as "hardened" by God ${ }^{18}$ until all plans with the gentile world will be fulfilled (v. 25); he classified their behavior, using scriptural language, as "iniquities" and "sins" (vv. 26-27); he claimed them to be God's (!19) "enemies" with regard to the gospel (v. 28). These are strongly negative terms. ${ }^{20}$ The language reveals in my view that Paul's attitude towards contemporary Judaism was, to say the least, ambivalent. I only want to add briefly here that it was Paul who wrote one of the worst antisemitic statements of the whole New Testament in his first epistle to the Thessalonians ${ }^{21}$ and who applied in his epistle to the Philippians in one passage the term "rubbish" to his Jewish roots, education, and way of life. ${ }^{22}$

Nevertheless, the passage Rom 11:11-36 altogether demonstrates that Paul "somehow" was convinced that in God's plan, there is a kind of particular way and a kind of eschatological happy end for God's chosen people as a whole. This was undoubtedly the crucial point, which he wanted his Roman addressees to understand.

\subsection{Expansion of Election and Deconstruction of Identity: Israel in the Epistle to the Ephesians}

According to the prescript (1:1-2), the epistle to the Ephesians was written by Paul. Paul, however, was in all likelihood not the author, rather, the epistle

17 See 11:21: God is behind all the actions concerning the branches.

18 See Rom 9:18 and 11:7-8: God is the subject of the hardening.

19 11:28 contains a carefully worked out antithetical parallelism. With regard to the meaning of

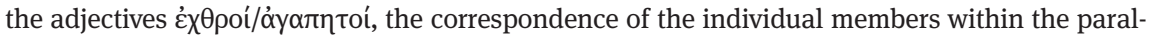
lelism requires to take $\dot{\chi} \chi \theta \rho o$ (corresponding $\alpha \dot{\gamma} \alpha \pi \eta \tau o$ ') in the passive sense, i.e., hated (and not in the active sense, i.e., enmity against God, thus, e. g., R. Jewett, Romans: A Commentary [Minneapolis: Fortress, 2007], 707), and referring to God (not to Paul nor to the Christians/the Christian gospel, thus, e.g., R. N. Longenecker, The Epistle to the Romans [Grand Rapids: Eerdmans, 2016], 901), as correctly pointed out by C. E. B. Cranfield, The Epistle to the Romans. Volume II, 5th ed. (Edinburgh: T\&T Clark, 1989), 580, and cf. furthermore Rom 9:13. D. Zeller, Der Brief an

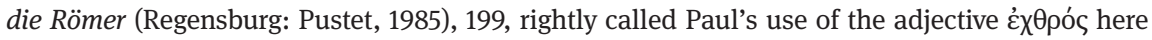
"shocking."

20 If Paul had known that the history of Christianity will last some thousand years more, he probably would have had written differently. Not least with regard to the different historical situation, Christians today are certainly not forced to adopt Paul's attitude towards contemporary Judaism, see Konrad, "Schriftprinzip," $122 \mathrm{f}$.

21 See 1 Thess 2:14-16.

22 See Phil 3:8. 
was written presumably only between 80 and 100 C.E. ${ }^{23}$ With regard to the status of Israel and to the idea of divine election, the views developed in this epistle are rather peculiar. A first crucial text is the eulogy (1:3-14). The eulogy consists of one long complex sentence, I quote only an extract:

1:3a Blessed (is) the God and father of our Lord Jesus Christ

3b who has blessed us with all spiritual blessing in heavenlies in Christ

4 according as he has chosen us in him (i.e., Christ) before the foundation of the world that we should be holy and blameless before him in love

5 having predestined us for adoption as children through Jesus Christ to himself (i.e., God) [...],

9 having made known to us the mystery of his will according to his good pleasure which he set forth in him (i.e., Christ)

10 as a plan for the fullness of times: to gather together all things in Christ [...].

In order to understand the content, it is necessary to briefly analyze the syntactical structure of the eulogy: ${ }^{24}$ After the opening with the Berakah formula in $\mathrm{v}$.

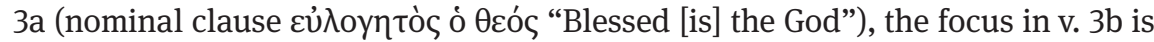

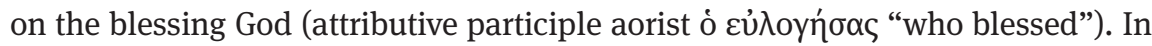
v. 4, God's blessing is specified as the election of "us" (referring to the author and the addressees ${ }^{25}$ ), and the election is claimed to be a pre-existent act which is linked to Jesus Christ. ${ }^{26}$ The meaning of the election, then, is spelled out in vv. 5-14 in two points: firstly, as adoption as children of God through the deliverance from sin granted by Jesus Christ (vv. 5-8, beginning with the

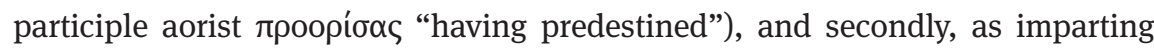

23 See G. Sellin, Der Brief an die Epheser (Göttingen: Vandenhoeck \& Ruprecht, 2008), 58. 24 In terms of syntax, the passage is extremely disputed, especially with regard to the relation-

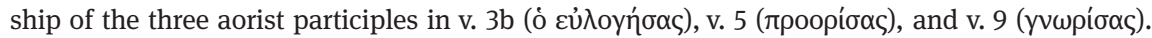
Many scholars take all three as attributive participles (meaning that the first participle is continued by the second and the third one), e.g., Sellin, Epheser, 75-81. However, neither the second

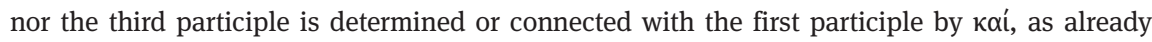
noticed by R. Deichgräber, Gotteshymnus und Christushymnus in der frühen Christenheit: Untersuchungen zu Form, Sprache und Stil der frühchristlichen Hymnen (Göttingen: Vandenhoeck \& Ru-

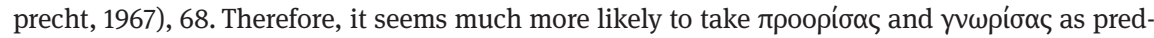

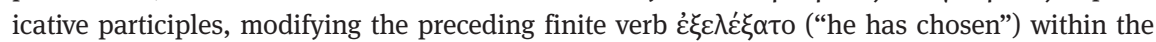
$\kappa \alpha \theta \dot{\omega} \varsigma$ clause ("according as ...”) in v. 4.

25 Cf. E. Best, Ephesians (Edinburgh: T\&T Clark, 1998), 114.

26 The author was in all likelihood inspired by the idea of the pre-temporal divine election of Israel according to several texts in Second Temple Judaism (e.g., JosAs 8:10, Ass Mos 1:14, and see Sellin, Epheser, 90 -91). 
of understanding of God's purpose for the cosmos including the summation of all things in Jesus Christ (vv. 9-14, beginning with the participle aorist

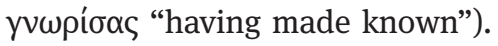

In light of the eulogy, then, there is only one effectual divine election, and this is the pre-temporal election in Jesus Christ. It is clearly implied that "not chosen" means in this case "not predestined for salvation." The Israel that would not accept Jesus Christ as Messiah may be called according to the Jewish Holy Scriptures or may understand itself as God's chosen people. However, this election would be of no consequence: the author of the eulogy left no doors open for acknowledging any legitimate relationship between God and Israel as his chosen people alongside this Christ-centered interpretation of God and his plans for the cosmos.

The reason to expand the idea of election on the one hand and to completely ignore or even repulse the idea of God's election of Israel on the other hand becomes all the more comprehensible, if we take a look at chapter 2 of the epistle. There, the author explains the meaning of the death of Jesus Christ. It may suffice to quote the vv. 14-16:

2:14 For he (i.e., Jesus Christ) is our peace who has made both (groups, i.e., Jews and Gentiles) into one (group) and (who) has broken down the wall of partition, the enmity, in his flesh,

15 (who) has abolished the law of commandments (contained) in ordinances that he might create in himself one new man/humanity in place of the two, thus making peace,

16 and (that) he might reconcile both (groups) to God in one body through the cross, thus having killed the enmity in it (i.e., the cross).

According to this text, the death of Jesus Christ aimed at deconstructing Israel's identity as well as the identity of the Gentiles in order to create "one new man/ humanity" (v. 15). In light of this aim, all Jewish religious ideas such as Torah and election could only appear as "hostile" (cf. the term है’ $\theta \rho \alpha$ in vv. 14, 16). To put it in another way: as long as this world would exist, ${ }^{27}$ Jews could, at least from the author's point of view, only be judged as "enemies."28

27 In distinction to Paul, the author of the epistle to the Ephesians did not show any interest in eschatology (including the parousia of Jesus Christ), see Sellin, Epheser, 109.

28 At least in my view, the comment on v. 16 given by U. Luz, "Der Brief an die Epheser," in Die Briefe an die Galater, Epheser und Kolosser, ed. J. Becker and U. Luz (Göttingen: Vandenhoeck \& Ruprecht, 1998), 107-82, 140, is rather enigmatic: 'Unser Verfasser zieht also das 'religiöse' Ereignis des Kreuzestodes in die Welt hinein, indem er die horizontale Dimension von 'Friede' und 'Versöhnung' betont. Damit leistet er nicht nur einen wichtigen Beitrag zur Kreuzestheologie, sondern auch zur Überwindung [!] des Antisemitismus seiner Zeit.” 


\subsection{Chosen Israel without Salvation: non-Christ-believing Jews in Acts 13}

The book the Acts of the Apostles was written by Luke presumably in the last decades of the first century C.E. Especially important with regard to the topic of this paper is Luke's narrative about Paul and his missionary activity in Pisidian Antioch in Acts 13. The vast majority of scholars agree that this narrative is not a faithful report about historical events. Rather, Luke, with help of this narrative, which includes a long sermon put into Paul's mouth, tried to explain to his readership from his point of view the theological message of the apostle. ${ }^{29}$ I will concentrate at first on the sermon (vv. 16b-41), of which only selected parts shall be quoted:

14 [...] They (i.e., Paul and his companions) [...] came to Pisidian Antioch, and they went into the synagogue on the Sabbath day and sat down.

15 After the reading of the law and the prophets, the officials of the synagogue sent to them, saying: "Fellow brothers, if you have any word of exhortation for the people, say it!"

16 So Paul stood up and, making a sign with his hand, he said: "Fellow Israelites, and you who fear God, listen:

17 The God of this people Israel chose our fathers and exalted the people during the sojourn in the land of Egypt, and with uplifted arm he brought them out of it. [...]

21 [...] And God gave them Saul [...].

22 And after having removed him, he raised up David for them to be king [...].

23 Of this man's seed God, according to (his) promise, has brought to Israel a saviour, Jesus. $[\ldots]$

26 Fellow brothers, sons of the family of Abraham, and those among you who fear God, to us the word of this salvation has been sent.

27 For the inhabitants of Jerusalem and their rulers fulfilled, because they did not recognize this man, even ${ }^{30}$ the voices of the prophets, which are read every Sabbath, in having condemned (him).

28 And although they found no cause of death, they asked Pilate, to have him executed.

29 See, for example, C. K. Barrett, Acts 1- XIV (Edinburgh: T\&T Clark, 1998), 625.

30 kaí is used here in a kind of "adverbial” function, see F. Blass et al., Grammatik des neutestamentlichen Griechisch, 18th ed. (Göttingen: Vandenhoeck \& Ruprecht, 2001), §442 (second sentence in the introduction to this paragraph); E. Bornemann and E. Risch, Griechische Grammatik,

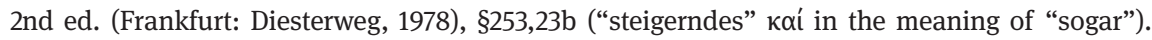
The active, transitive verb $\pi \lambda \eta$ pó $\omega$ requires a direct object. 
29 And when they had completed all that is written about him, after having taken (him) down from the tree (i.e., the cross), they laid him in a tomb.

30 But God raised him from the dead. [...]

38 So let it be known to you, fellow brothers, that through this man forgiveness of sins is proclaimed to you, and (that) from everything from which you could not be justified by the law of Moses

39 in this man everyone who believes is justified. [...]"

For Lukan Paul (as for the historical Paul), the history of Israel begins with God's election of the people (via the patriarchs, v. $17^{31}$ ). It is this elect people (as represented by the house of David) that received God's promise, to bring a savior who is identified as Jesus Christ (v. 23). For the death of this savior, Lukan Paul does not blame the Romans, but he does hold responsible-as also the historical Paul and many others did-the Jewish inhabitants of Jerusalem and their rulers, alleging them to have acted in a malicious manner (vv. 27-28). ${ }^{32}$ However, the Jewish communities outside of Jerusalem may make their own decision with regard to this savior, as Lukan Paul explains in the concluding part of his sermon (vv. 38-41). In this part, it is of particular interest that "forgiveness of sins" and "justification" 33 are linked exclusively to Jesus Christ (vv. 38-39). As a consequence of this exclusive linkage, Jews, who would not accept Jesus Christ as their savior, are automatically denied, although they are part of the chosen people, to have any possibility to gain forgiveness (for example at Yom Kippur) or to hold the attribute "just," when acting according to the mosaic Torah and Halakha alone.

I will now turn to Luke's narrative about the reactions of the population to the sermon (vv. 42-51). Most problematic is the picture, which Luke drew of the Jews, who did not accept the way that was being offered to them by Paul. It may suffice to quote a few sentences:

31 Cf. Rom 11:28 above.

32 It is one of the main antisemitic stereotypes in the New Testament that the Jews are responsible for the death of Jesus Christ (see, e.g., Matt 27:24-25; John 8:43-44; 1 Thess 2:14-16). See Theissen, "Aporien," 537-39.

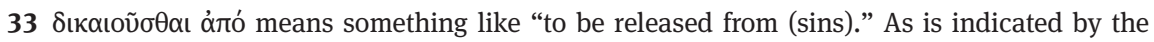
aorist ( $\delta เ \kappa \alpha \iota \omega \theta \tilde{\eta} v \alpha \iota)$, the author had a punctual event or punctual events in mind and did not mean justification in the Pauline sense, see C. Burchard, Der dreizehnte Zeuge: Traditionsund kompositionsgeschichtliche Untersuchungen zu Lukas’ Darstellung der Frühzeit des Paulus (Göttingen: Vandenhoeck \& Ruprecht, 1970), 117n258; Barrett, Acts, 650-51. 
44 And the next Sabbath almost the whole city gathered to hear the word of the Lord. 45 But when seeing the crowds, the Jews were filled with envy and began to contradict what was spoken by Paul, blaspheming.

46 And Paul and Barnabas spoke out boldly, saying: "It was necessary that the word of God should be spoken first of all to you. Since you thrust it and you judge yourself to be not worthy of eternal life, behold, we are turning to the Gentiles.

47 For so the Lord has commanded us: 'I have made you a light for the Gentiles, so that you may bring salvation to the ends of the earth.” [...]

50 And the Jews incited the devout women [...] and leading men of the city, and they raised a persecution against Paul and Barnabas and drove them out of their borders.

In this narrative, we find not only a revealing generalization: non-Christ-believing Judaism is equated with "the Jews." But we find also a depreciative language with regard to "the Jews": the application of the categories "envy," "blasphemy," and "incitement." In light of these categories, the narrated rejection of the salvation offer does not only seem highly irrational, but it also seems to be a kind of moral and religious self-disqualification. ${ }^{34}$ Luke did not offer in his book any further remarks to soften or to modify this picture. ${ }^{35}$ How, then, would it be possible for the readers of Luke to think anything positive about non-Christ-believing Judaism?

\section{Antisemitic Positions in Christian Holy Scriptures: The Challenge for today's Christian Readership}

In all the analyzed New Testament texts, the authors expressed in their own ways their depreciation of the non-Christ-believing Israel, underlined with pejorative emotional terms and statements. The rationale is the shared belief that Judaism as such is actually not worth being protected and preserved, since the focus is all on Jesus Christ and the universal consequences of his death-and it is precisely this rationale which makes it in my view impossible to relate the analyzed texts

34 In this passage, it is not God who (actively) rejected the non-Christ-believing Jews, contra E. Haenchen, Die Apostelgeschichte, 7th ed. (Göttingen: Vandenhoeck \& Ruprecht, 1977), 397.

35 In Acts, non-Christ-believing Jews are constructed as Paul's particularly dangerous, lifethreatening enemies during his missionary activities (see, e.g., Acts 14:4, 19; 17:5, 13; 18:12; 20:3; 21:27; 22:22; 23:12). 
to Jewish texts in Second Temple Judaism that indicate indeed many controversial inner-Jewish discourses about religious identity ${ }^{36}$ (the expressions of depreciation in the New Testament texts are not expressions of a dispute among "siblings"). ${ }^{37}$ It is hardly surprising, then, that Supersessionism was a dominant pattern in the history of the Christian religion: ${ }^{38}$ Christians have claimed to be the rightfully chosen people and the "true Israel" and have claimed the Jews to be rejected by God. Or in other words: the New Covenant was believed to have superseded the old Mosaic Covenant. I would just like to draw attention again to Luther's statements, quoted at the beginning of this article.

It may be relevant to present one more example from the field of arts, namely the figures of ecclesia and synagogue, which can be found as a pair in many medieval cathedrals:

Both figures are a kind of artistic realization of Supersessionism: ecclesia in the position of triumph, synagogue in the position of weakness and defeat (blind with a broken lance and falling tablets of the law).

It was only after the Shoah that at least some of the main Christian churches in Germany and elsewhere started to reconsider their positions towards Judaism, for example, explicitly rejecting the view that Israel ceased to be God's chosen people. ${ }^{39}$ This leads to the crucial question, if it is indeed possible to (re)define the substance and identity of the Christian religion as a religion without antisem-

36 For example, in the eyes of the authors of the Damascus Document, Jewish identity must include a life according to Torah and Halakha (i.e., Halakha as presented in the CD), see K. Finsterbusch, “Konstruktionen kollektiver Identität in der Krise: 'Israel' nach dem exilischen Deuteronomium und der Damaskusschrift," in Konstruktionen individueller und kollektiver Identität (I), ed. K. Finsterbusch and E. Bons (Neukirchen-Vluyn: Neukirchener Theologie, 2016), 109-31. 37 In historical terms, the relationship(s) between Christian and Jewish groups in the first and second century C.E. may have been rather complex. In scholarly literature, terms like "parting" or "partings" of the ways are discussed, see, for example, J. D. G. Dunn, The Partings of the Ways between Christianity and Judaism and their Significance for the Character of Christianity, 2nd ed. (London: SCM Press, 2006); T. Nicklas, "Parting of the Ways? Probleme eines Konzepts," in Juden -Heiden-Christen? Religiöse Inklusionen und Exklusionen im Römischen Kleinasien bis Decius, ed. S. Alkier and H. Leppin (Tübingen: Mohr Siebeck, 2018), 21-42.

38 See R. Kampling, "Substitutionslehre," in Handbuch des Antisemitismus: Judenfeindschaft in Geschichte und Gegenwart. Vol. 3 Begriffe, Theorien, Ideologien, ed. W. Benz et al. (Berlin: De Gruyter, 2010), 310-12.

39 For relevant references, see, for example, N. Lohfink and E. Zenger, Der Gott Israels und die Völker (Stuttgart: Katholisches Bibelwerk, 1994), 11-18; M. Goldmann, 'Die große ökumenische Frage ...' Zur Strukturverschiedenheit christlicher und jüdischer Tradition und ihrer Relevanz für die Begegnung der Kirche mit Israel (Neukirchen-Vluyn: Neukirchener Verlag, 1997), 386-89; T. Czopf, Neues Volk Gottes? Zur Geschichte und Problematik eines Begriffs (Sankt Ottilien: Eos Verlag, 2016). 


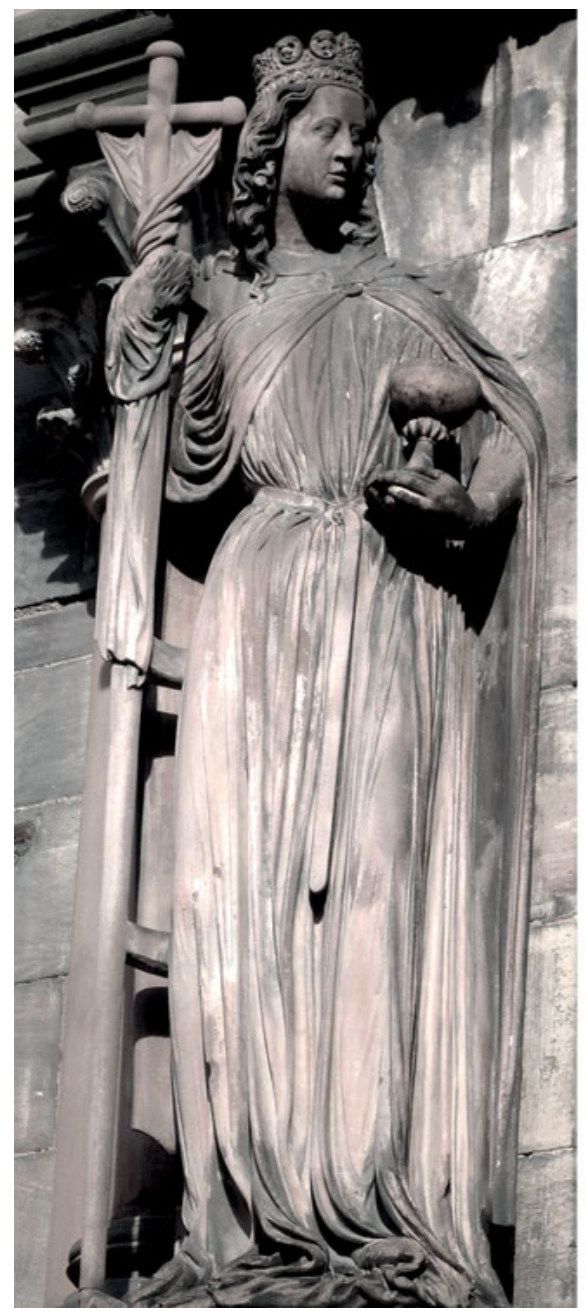

Fig. 1: The figure of ecclesia at the cathedral of Strasbourg.

Source: "Figur der Ecclesia mit Krone, römischem Vexillum und Messkelch. Straßburg, Cathédrale Notre-Dame."

(c) Claude Truong-Ngoc. https://de.wikipedia. org/wiki/Ecclesia_und_Synagoge\#/media/ Datei:Strasbourg_Cath\%C3\%A9drale_Notre_ Dame_statue_de_l'Eglise.jpg, accessed June 19, 2020.

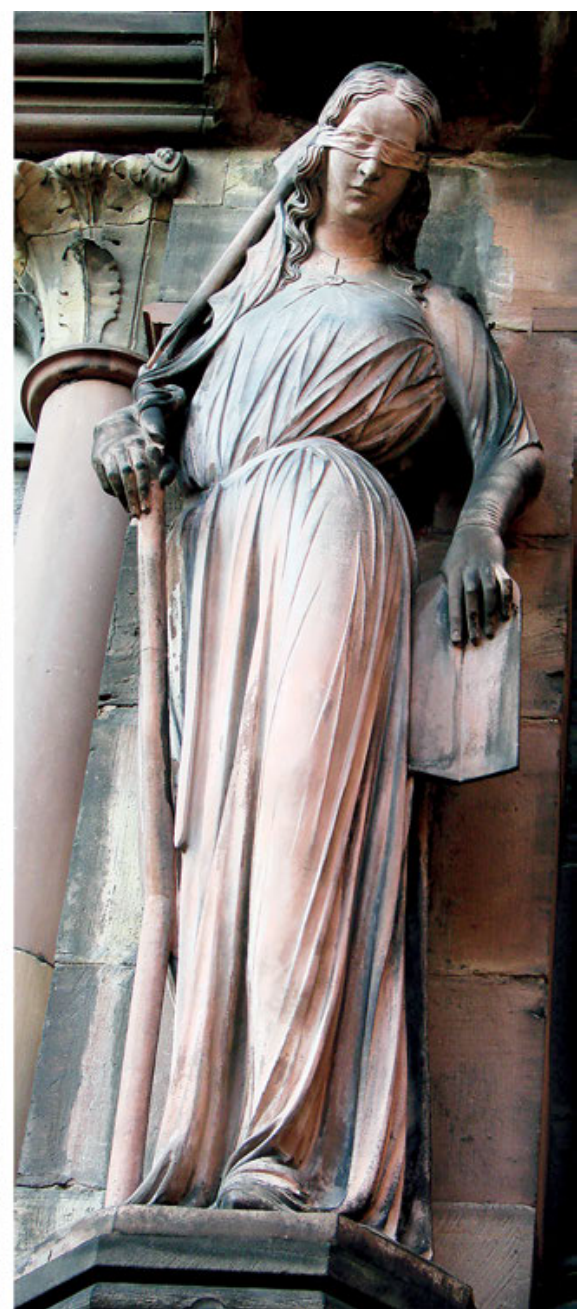

Fig. 2: The figure of synagogue at the cathedral of Strasbourg.

Source: https://de.wikipedia.org/wiki/Eccle sia_und_Synagoge\#/media/Datei:ND_strasb_ synagogue.jpg, accessed June 19, 2020. 
itic elements. I would like to conclude with three considerations about the meaning of the Holy Scriptures for such a process of (re)definition-which would of course be necessary in every generation anew:

1. The Christian Bible with regard to its two parts, the Old Testament and the New Testament, is not a dogmatic text but a dynamic document. There are often several differing, multi-perspective positions (from different authors, written in different contexts and epochs) about one and the same issue. They were put together secondarily and this undoubtedly in order to allow, to encourage, or even to urge the readership or addressed communities to critically discuss, to choose, to shape positions and to take sides in a changing world. To put it in another way: the biblical texts themselves do by no means require that every single passage must be read and accepted in a fundamentalist way.

2. The Christian Old Testament is (grosso modo) the Tanakh in Judaism. The scriptures are shared heritage and valued canonical texts for both religions. ${ }^{40}$ As a consequence, it is in my view impossible for Christians to declare the daily liturgical Jewish prayers to God, which are in part deeply rooted in the Scriptures, as invalid or inferior.

3. With regard to the status of Israel in the New Testament, Rom 11:26-27 ("all Israel will be saved") could be a point of departure to develop a position, which would include the full acceptance ${ }^{41}$ of Judaism alongside the Christian sector in the "divine economy." 42 Statements on non-Christ-believing Jews, however, comparing them with branches of an olive tree that were broken off by God or views on Israel like those expressed in Eph 2:14-16 or in Acts 13, should be abrogated altogether.

40 Several times in the history of Christianity, the canonical status of the Old Testament was disputed. For a recent debate, see F. Hartenstein, "Zur Bedeutung des Alten Testaments für die evangelische Kirche: Eine Auseinandersetzung mit den Thesen von Notger Slenczka,” Theologische Literaturzeitung 140 (2015): 738 - 51, who rightly defends the position that the Old Testament is an indispensable part of the Christian Bible and essential for Christianity.

41 Cf. the statement "The Gifts and the Calling of God are Irrevocable" which was released by the pontifical "Commission for Religious Relations with the Jews" in October 2015, on the fiftieth anniversary of Nostra Aetate, section 36: "That the Jews are participants in God's salvation is theologically unquestionable, but how that can be possible without confessing Christ explicitly, is and remains an unfathomable divine mystery."

42 This expression is taken from Plaut, Case, 54-55. 
Karin Finsterbusch is Professor for Old Testament/Hebrew Bible at the University of Koblenz-Landau (Landau). Her research specializes in the Book of Deuteronomy, prophetic literature, and the textual criticism of the Hebrew Bible. She has published widely on all these research areas.

\section{Bibliography}

\section{Primary Sources}

Barrett, Charles K. Acts 1- XIV. Edinburgh: T\&T Clark, 1998.

Best, E. Ephesians. Edinburgh: T\&T Clark, 1998.

Blass, Friedrich, et al. Grammatik des neutestamentlichen Griechisch. 18th ed. Göttingen: Vandenhoeck \& Ruprecht, 2001.

Bornemann, Eduard, and Ernst Risch. Griechische Grammatik. 2nd ed. Frankfurt: Diesterweg, 1978.

Cranfield, C. E. B. A Critical and Exegetical Commentary on the Epistle to the Romans. 5th ed. Vol 2. Edinburgh: T\&T Clark, 1989.

Haenchen, Ernst. Die Apostelgeschichte. 7th ed. Göttingen: Vandenhoeck \& Ruprecht, 1977. Jewett, Robert. Romans: A Commentary. Minneapolis: Fortress, 2007.

Longenecker, Richard N. The Epistle to the Romans: A Commentary on the Greek Text. Grand Rapids: Eerdmans, 2016.

Luther, Martin. Von den Jüden und jren Lügen (1543). WA 53, 412-552.

Luz, Ulrich. "Der Brief an die Epheser." In Die Briefe an die Galater, Epheser und Kolosser, edited by Jürgen Becker and Ulrich Luz, 107-82. Göttingen: Vandenhoeck \& Ruprecht, 1998.

Sellin, Gerhard. Der Brief an die Epheser. Göttingen: Vandenhoeck \& Ruprecht, 2008.

Zeller, Dieter. Der Brief an die Römer. Regensburg: Pustet, 1985.

\section{Secondary Sources}

Almog, Shmuel, and Michael Heyd, eds. Chosen People, Elect Nation and Universal Mission. Jerusalem: Graf-Chen, 1991. [Hebrew]

Bieringer, Reimund, Didier Pollefeyt, and F. Vandecasteele-Vanneuville, eds. Anti-Judaism and the Fourth Gospel: Papers of the Leuven Colloquium. Assen: Van Gorcum, 2001.

Burchard, Christoph. Der dreizehnte Zeuge: Traditions- und kompositionsgeschichtliche Untersuchungen zu Lukas' Darstellung der Frühzeit des Paulus. Göttingen: Vandenhoeck \& Ruprecht, 1970.

Chazan, Robert. From Anti-Judaism to Anti-Semitism: Ancient and Medieval Christian Constructions of Jewish History. New York: Cambridge University Press, 2016.

Czopf, Tamás. Neues Volk Gottes? Zur Geschichte und Problematik eines Begriffs. St. Ottilien: Eos Verlag, 2016. 
Deichgräber, Reinhard. Gotteshymnus und Christushymnus in der frühen Christenheit: Untersuchungen zu Form, Sprache und Stil der frühchristlichen Hymnen. Göttingen: Vandenhoeck \& Ruprecht, 1967.

Dietrich, Walter, et al., eds. Antijudaismus-christliche Erblast. Stuttgart: Kohlhammer, 1999.

Donaldson, Terry L. Jews and Anti-Judaism in the New Testament: Decision Points and Divergent Interpretation. London: Baylor University Press, 2010.

Dunn, James D. G. The Partings of the Ways between Christianity and Judaism and their Significance for the Character of Christianity. 2nd ed. London: SCM Press, 2006.

Eckert, Paul, Nathan Peter Levinson, and Martin Stöhr, eds. Antijudaismus im Neuen Testament? Exegetische und systematische Beiträge. Munich: Kaiser, 1967.

Finsterbusch, Karin. Deuteronomium: Eine Einführung. Göttingen: Vandenhoeck \& Ruprecht, 2012.

Finsterbusch, Karin. “Konstruktionen kollektiver Identität in der Krise: 'Israel’ nach dem exilischen Deuteronomium und der Damaskusschrift." In Konstruktionen individueller und kollektiver Identität (I), edited by Karin Finsterbusch and Eberhard Bons, 109-31. Neukirchen-Vluyn: Neukirchener Theologie, 2016.

Goldmann, Manuel. 'Die große ökumenische Frage ...' Zur Strukturverschiedenheit christlicher und jüdischer Tradition und ihrer Relevanz für die Begegnung der Kirche mit Israel. Neukirchen-Vluyn: Neukirchener Verlag, 1997.

Gellman, Jerome. “Jewish Chosenness and Religious Diversity-A Contemporary Approach." In Religious Perspectives on Religious Diversity, edited by Robert McKim, 21-36. Leiden: Brill, 2016.

Grindheim, Sigurd. The Crux of Election: Paul's Critique of the Jewish Confidence in the Election of Israel. Tübingen: Mohr Siebeck, 2005.

Hartenstein, Friedhelm. "Zur Bedeutung des Alten Testaments für die evangelische Kirche: Eine Auseinandersetzung mit den Thesen von Notger Slenczka." Theologische Literaturzeitung 140 (2015): $738-51$.

Herberg, Will. "The 'Chosenness' of Israel and the 'Jew' of today." In Arguments and Doctrines: A Reader of Jewish Thinking in the Aftermath of the Holocaust, edited by Arthur A. Cohen, 267-83. New York: Harper \& Row, 1970.

Kahana, Menahem. "Pages from the Deuteronomy Mekhilta on Haazinu and Wezot Haberakha." Tarbitz 57 (1988): 165-201. [Hebrew]

Kampling, Rainer. "Substitutionslehre." In Handbuch des Antisemitismus: Judenfeindschaft in Geschichte und Gegenwart. Vol. 3 Begriffe, Theorien, Ideologien, edited by Wolfgang Benz et al., 310-12. Berlin: De Gruyter, 2010.

Konradt, Matthias. "Die historisch-kritische Exegese und das reformatorische Schriftprinzip: Eine Reflexion über die Bedeutung der Exegese des Neuen Testaments in der Theologie." Zeitschrift für Neues Testament 39/40 (2017): 105-25.

Lohfink, Gerhard. "Antijudaismus bei Paulus?" In Im Ringen um die Vernunft: Reden über Israel, die Kirche und die Europäische Aufklärung, 335-66. Freiburg: Herder, 2016.

Lohfink, Norbert, and Erich Zenger. Der Gott Israels und die Völker. Stuttgart: Katholisches Bibelwerk, 1994.

Mussner, Franz. "Ganz Israel wird gerettet werden (Röm 11,26): Versuch einer Auslegung." Kairos 18 (1976): 241-55.

Mussner, Franz. Traktat über die Juden. Munich: Kösel, 1979. 
Nicklas, Tobias. "Parting of the Ways? Probleme eines Konzepts. "In Juden-HeidenChristen? Religiöse Inklusionen und Exklusionen im Römischen Kleinasien bis Decius, edited by Stefan Alkier and Hartmut Leppin, 21-42. Tübingen: Mohr Siebeck, 2018.

Novak, David. "The Election of Israel: Outline of a Philosophical Analysis." In A People Apart: Chosenness and Ritual in Jewish Philosophical Thought, edited by Daniel H. Frank, 11-50. New York: State University Press, 1993.

Novak, David. The Image of the non-Jew in Judaism: The Idea of the Noahide Law. 2nd ed. Oxford: The Littman Library of Jewish Civilization, 2011.

Plaut, W. Gunther. The Case for the Chosen People. Garden City: Doubleday, 1965.

Radford Ruether, Rosemary. Faith and Fratricide: The Theological Roots of Anti-Semitism. New York: Seabury, 1974.

Seybold, Klaus. “Erwählung. I Altes Testament.” In Religion in Geschichte und Gegenwart: Handwörterbuch für Theologie und Religionswissenschaft, edited by Hans Dieter Betz, 4th ed., 2:1478-81. Tübingen: Mohr Siebeck, 1999.

Silberman, Lou H. "Chosen People." In Encyclopaedia Judaica, edited by Fred Skolnik and Michael Berenbaum, 2nd ed., 4:699-72. Detroit: Macmillan Reference, 2007.

Theissen, Gerd. “Aporien im Umgang mit den Antijudaismen des Neuen Testaments.” In Die Hebräische Bibel und ihre zweifache Nachgeschichte. FS R. Rendtorff, edited by Erhard Blum, Christian Macholz, and Ekkehard W. Stegemann , 535-53. Neukirchen-Vluyn: Neukirchener Verlag, 1990.

Tigay, Jeffrey H. Deuteronomy. Philadelphia: Jewish Publication Society, 1996.

Vollenweider, Samuel. “Antijudaismus im Neuen Testament: Der Anfang einer unseligen Tradition." In Antijudaismus-christliche Erblast, edited by Walter Dietrich, Martin George, and Ulrich Luz, 40-55. Stuttgart: Kohlhammer, 1999.

Wendebourg, Dorothea, et al., eds. Protestantismus, Antijudaismus, Antisemitismus: Konvergenzen und Konfrontationen in ihren Kontexten. Tübingen: Mohr Siebeck, 2017.

Wien, Ulrich Andreas, ed. Judentum und Antisemitismus in Europa. Tübingen: Mohr Siebeck, 2017.

Wyschogrod, Michael. The Body of Faith: Judaism as Corporeal Election. Minneapolis: Seabury, 1983. 